\title{
DESIGNING A REGIONAL POLICY OF AGROTOURISM - THE CASE OF AUVERGNE REGION (FRANCE)
}

\author{
Jean-Bernard Marsat ${ }^{1}$, Pauline Menegazzi, Céline Monin, \\ Aurore Bonniot, Monique Bouchaud
}

Received 20 November 2012; Accepted 20 September 2013

\begin{abstract}
The present article reports the meeting of a research program on rural tourism with the need of knowledge expressed for a new policy in favour of agritourism, led by the Region Auvergne (France). The research program (Modintour, 2008-2011) dealt with models of tourism and studied the territorial integration of tourism. Integration of tourism develops complementarities with other local activities. Indeed agritourism is an activity which associates two distinctive sectors. The empirical study shows some importance of agritourism for the local offer, especially in the destinations of dispersed tourism. It highlights the diversity of the logics of the farmers and of their networks. It shows the relevance of support already available for the farmers through consular chamber and networks. But it shows also the stake of better cooperation between networks, the need to link the existing support system to the specialised tourism bodies, and the need for a renewed common strategy.
\end{abstract}

Keywords: tourism; agritourism; integrated tourism; coordination; networks; public policy

Résumé: L'article expose le résultat d'une rencontre entre un programme de recherche sur le tourisme rural et le besoin de connaissances nécessaires à une nouvelle politique en faveur de l'agritourisme, conduite par la Région Auvergne (France). Le programme de recherche (Modintour, 2008-2011) traitait de modèles de tourisme et étudiait l'intégration territoriale du tourisme. Cette intégration développe les complémentarités du tourisme avec les autres activités locales. Et l'agritourisme est une activité qui associe bien deux secteurs distincts. L'étude empirique montre une certaine importance de l'agritourisme pour l'offre touristique locale, spécialement dans les destinations de tourisme diffus. Elle rend compte de la diversité des logiques des agriculteurs et de leurs réseaux. Elle montre la pertinence du soutien apporté aux agriculteurs par les chambres consulaires et les réseaux. Mais elle montre aussi l'enjeu d'une meilleure coopération entre les réseaux, le besoin de mieux connecter le système d'appui actuel aux autres organisations spécialisées en tourisme, et le besoin d'une stratégie renouvelée et commune.

Mots-clés: tourisme; agritourisme; tourisme intégré; coordination; réseaux; politique publique

\footnotetext{
${ }^{1}$ Irstea, UMR Métafort, F-63170 Aubière, France, AgroParisTech, UMR Métafort, F-63170 Aubière, France, Clermont Université, VetAgroSup, UMR Métafort, F-63370 Lempdes, Inra, UMR1273 Métafort, F-63122 Saint-Genes Champanelle, France; jean-bernard.marsat@irstea.fr
} 


\section{Introduction}

Agritourism is an activity which associates two distinctive sectors, with their proper characteristics, in the economic, professional, organizational fields. Up to now agritourism was mostly considered and studied in relation to agricultural stakes, as the diversification of an agricultural activity. It was less considered in relation to specific stakes of tourism, and in relation to the local territorial framework of the "tourist destination".

The present article reports part of a study which stemmed from the meeting of our research on territorial integration and governance of rural tourism, with the wish of knowledge expressed by a regional organization recently in charge of a new policy in favour of agritourism.

In the case of the region Auvergne, the Regional institution wanted to help more efficiently the farmers to find more revenue, and/or employment by the way of diversification in agritourism. It asked recently the Regional Tourism Committee (CRT) to take this policy in charge. The CRT is leading a very active policy for the development of tourism but has to know more on agritourism in order to set up a very specific strategy.

In the same time, researchers involved in a program about the models of tourism (MODINTOUR) were studying the governance and the territorial integration of tourism. This last concept is adapted from the framework and results of EU research program SPRITE (Jenkins, 2001). Territorial integration includes developing complementarities with other local activities. The approach is organizational and managerial, the research questions relate to the stakes and to the forms of coordination and governance. Concerning agritourism, this work has to take into account the specificity and the diversity of actors' logics in the agricultural domain, both at the individual and at the institutional levels.

The main question is: how to articulate the specific organization of agritourism (networks and public support, e.g. by the consular chamber) and the recent forms of organization in the tourism domain, which the CRT encourages vigorously?

\section{Theoretical framework}

Several approaches and models build our theoretical framework.

\subsection{Models of Tourism}

\section{Diffuse and concentrated tourism}

Actors frequently see an opposition between concentrated tourism that is considered to be disconnected from the territory and its inhabitants, and diffuse tourism that is considered to be suffering from the weakness of its economic outcomes.

Concentrated tourism is defined in the literature as referring to tourist resorts, or to "mass" tourism (Bachimon 1995). Diffuse tourism is defined either in a positive way as an alternative to the phenomena of the saturation of mass tourism (Knafou 1995), or in a less flattering way, "with an idea of dispersion". Through agritourism, (Violier 1995) has researched an example of diffuse tourism that is not the result of the diffusion of concentrated tourism, but the result of individual initiatives by versatile entrepreneurs within a diversified area.

We hypothesize that the dimension in which diffuse and concentrated tourism confront each other, dimension which we call the "density" of tourism, can be broken down into three subdimensions: "spatial", "temporal", and "organizational" ones (Marsat and Bonniot 2009). We therefore assume that great diversity exists in tourist destinations, forming a range of mixed or hybrid situations, between the all-diffuse and all-concentrated extremes.

\section{Integrated tourism}

The model of tourism called "integrated tourism" (IT) refers explicitly to a tourism which is linked to most of the economic, social, cultural, natural, and human structures of the areas in which it takes place (Jenkins, Oliver et al. 2001). The model proposes seven dimensions for the characterization and evaluation of integration. We retained for the present research: 
the "complementarity" of tourism with other activities of the territory (economic, social, or environmental activities), - "its social embeddedness" (relation to the population), - and its governance (networking, local control, ...). Agritourism is one of the major examples of complementarity between tourism and another economic sector.

We put forward the hypothesis that a better integration of tourism leads to an improvement of its economic effectiveness in the case of more diffuse tourism and to lessening of its negative impacts on the territory in the case of more concentrated tourism. Second hypothesis is that developing Agritourism is a factor of better territorial integration of diffuse tourism.

\section{Tourism as a production of a service by the destination territory}

Finally, tourism is a service activity. Both the economic and the management theories of services have proposed a triangular model of service activity. The "triangle of service" has two poles representing respectively the beneficiary and the service provider, and also a third pole called "support-good of the service". In addition, the managerial theory of the "production of the service" (servuction) distinguishes inside of the pole "provider", the components that are in contact with the beneficiary-client (the front-office), and the components that support the provision of the service (the back-office) (Eiglier and Langeard, 1987).

This model was transposed from the business scale to the territorial one by the research team of Interreg European Program Porta Natura (2003-2006). The entire territory is considered as the tourist service provider. All local actors constitute the "service provider" pole. The infrastructures which are dedicated to tourism, but also the features which are nondedicated, called natural or cultural "amenities" (OCDE 2000), constitute the pole "support-good of the service". In the Modintour program, we continued to improve and to test this model by incorporating the concepts and dimensions of territorial integrated tourism (Marsat, Brault et al. 2009; Marsat and Bonniot 2010).

As shown in the figure 1, farmers in a tourist destination belong to the tourist system due to two kinds of roles: 1- their taking care of the space, the landscapes, most of the amenities which belong to the pole "support-good of service" (or inversely their possible negative impacts on them), 2- the action of those who are involved in agritourism, directly addressed to the tourists, as service providers.

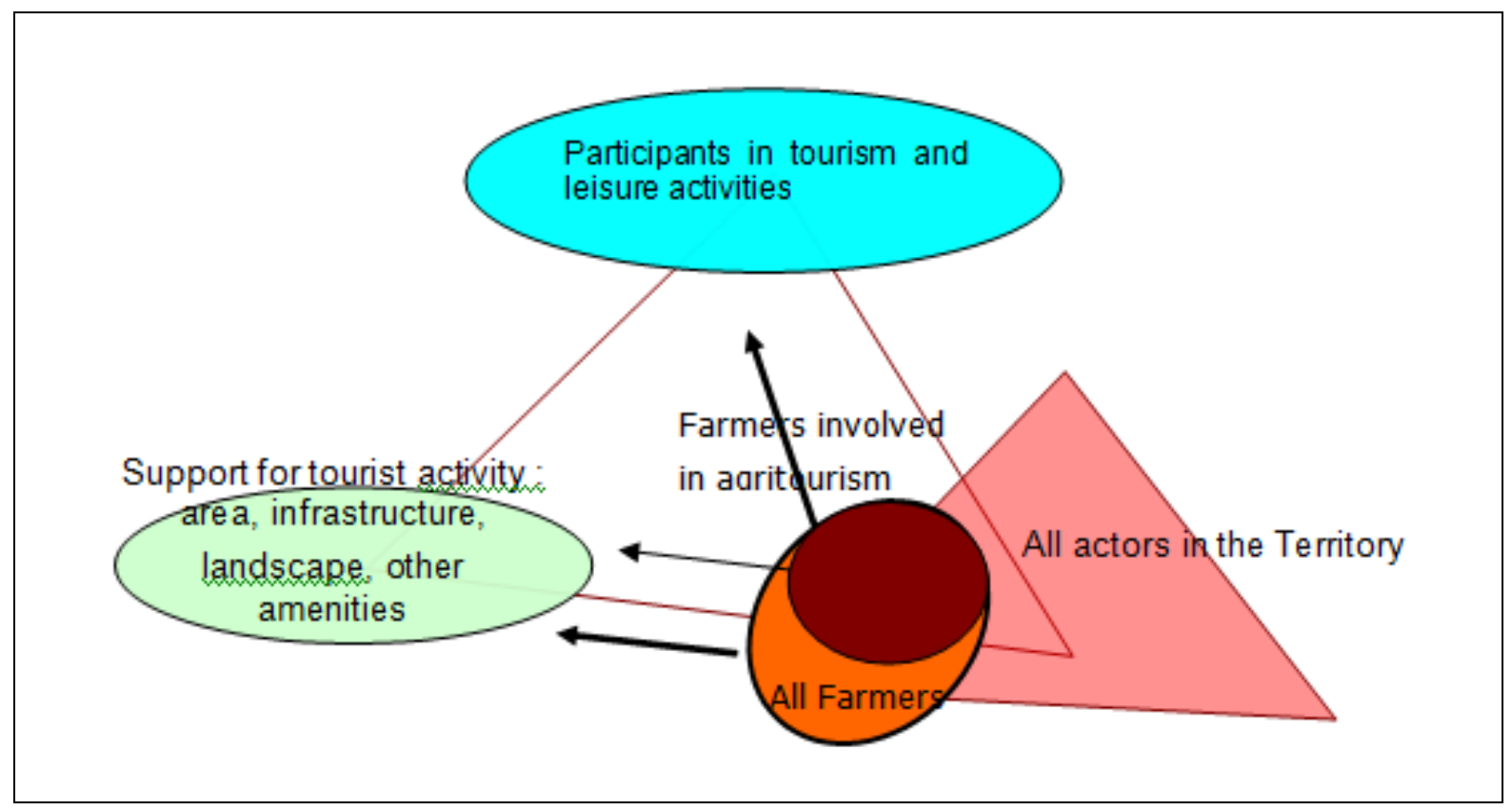

Fig 1. The place of farmers in the model of territorial servuction, derived from (Marsat, Brault et al. 2009). 


\subsection{Coordination and governance in tourism, management of a tourist destination Cooperation, networks}

Tourism offers almost simultaneously a wide range of services to a unique customer, the tourist. It leads to the necessity of cooperation between numerous actors. Rural tourism and especially diffuse tourism are supposed to entrain low economic impacts. In this domain, perhaps more than in overall tourism, collaboration is a necessity (Selin 1993).

The general literature on economic cooperation, collective strategies and on networks is very wide. The following shortlist includes different perspectives ${ }^{2}$, from which one may gather some main concepts. (Fombrun and Astley 1983) proposed a typology of collective strategies. (Jarillo 1988) stressed the role of the networks in reducing the transaction costs. The Swedish model of $B$ to $B$ networks presents a three-levelled structure which links actors, activities and resources (Hakansson and Sharma 1996). (Miles and Snow 1986) identify pivotal actors called "brokers" who play the role of architect of the network, and/or the role of facilitator.

In the domain of tourism, many authors stressed the importance of networks in diverse applications: for the delivery of a global tourism service (Tremblay 1998), or more specifically for marketing the destination (Buhalis 2000), for gaining competence in sustainable development (Halme 2001), for (events) strategy making (Stokes 2003), for building (wine) roads (Telfer 2000; Vandecandelaere and Touzard 2001).

\section{Global coordination, governance, management}

Cooperation may concern a homogeneous population of businesses (e.g. in the same activity such as catering: Astley and Fombrun name it "commensalism"), but more generally tourism involves many types of actors, and the need of coordination is global. For example (Marsat and Guerra 2011) assessed a need expressed by the entrepreneurs themselves for more help in order to enhance their "systems of relation". This help could come from existing networks, or from institutional actors. (Berger-Doucé 2004), (Halme 2001) or (Gundolf, Jaouen, and Loup 2006) confirmed the possible role of institutional actors in cooperative coordination. (Marsat 2007) identified the possible strategic objectives the (institutional) pivotal actor may strive towards. Inversely (Cattellin 2008) stresses that some actors may not consider the destination as a network, and that divergence and conflicts may occur. (Callegati and Grandi 2004; Fabry 2009; Huybers and Bennett 2003) or (Novelli, Schmitz, and Spencer 2006) refer to the concept of clusters (Porter 1980).

As indicated in the section 1.3, all local actors may be important for the tourism system. Coordination concerns public and private actors, businesses, NGO, inhabitants. For example (Dredge 2006) stresses the necessity to manage the relationship between the active tourism network and the whole local community, (Sheehan and Ritchie 2005) explore the diversity of the stakeholders and (Truly-Sauter and Leisen 1999) suggest to take care of the congruency of their logics. A large literature, mostly oriented on the dynamic of projects and of tourism planning, draws from the "collaboration theory" of (Gray 1989) : (Bramwell and Sharman 1999; Jamal and Getz 1995; Selin and Chavez 1995; Vernon, Essex, Pinder, and Curry 2005).

Last, the stake of coordination concerns also wider scales than the destination's one: on one hand local destinations are embedded in wider ones, on the other hand tourism is also structured in activities which have their own forms of organisation and networks. In the next section the general multi-scale organisation of tourism in France will be briefly exposed, and in following sections the specific organisation of agritourism will be also presented.

\section{Information about the coordination of tourism in France}

In France the responsibility for governing tourism activity is given by the law to public territorial bodies. This responsibility is shared between all nested scales: the local "communes" (presently most frequently "groups of communes"), the "départements" and the "régions". These bodies created specialised organizations for assisting them in matter of tourism: the local "tourist

\footnotetext{
${ }^{2}$ We omit here literature on social networks and policy networks.
} 
offices" (TO), and Tourist Committees at the scale of the Département (CDT) and of the Région (CRT). Tourist Offices may be of public or private (NGO) legal status, but both forms are very dependant on public finance.

So a multi-scaled set of (semi-)public organisational bodies is in charge of all facets of tourism. One of our main research questions is to know how efficient is the relation between this general tourism organisation and the specific organisation of agritourism.

\subsection{Specific knowledge on agritourism}

Some specific knowledge on agritourism is selected here, mostly in relation to this problematic of public policy, governance and coordination.

\section{Definition and scope of agritourism}

We adopt the wider definition of agritourism, drawing on (Perret et Marcelpoil, 2001): all forms of practices in tourism, individual as collective, whatever the status of their responsible (head of the farm, parent, salaried worker, retired farmer). But, for these authors, agritourism does not include punctual tourist activities led outside of the farm (like working in a ski resort). A national study takes also into account pluri-active farmers, associations including farmers, and every person which can be considered as farmer and offers tourist services related to a farm activity (AFIT, 1998).

Agritourism is the most widespread form of diversification of farms towards services (Simon, 2002). (Violier, 1995) distinguishes five types of tourist products according to the degree of integration of both farming and tourist activities. For him, the form of diversification through products (production on the farm) can concern tourism and leisure activities when the farmer sells his products directly, and thus falls in the scope of agritourism.

Anglo-Saxons distinguish two agritourism practices: tourism on farms, when the environment and the essence of the farm are an integral part of the product (for example: help with work on the farm, tractor rides, harvesting... farm stays) and farm tourism, when the accommodation is not located on the farm, such as a country cottage (Ilbery, Bowler, Clark, Crockette, and Shaw 1998).

\section{Quantitative importance of agritourism}

In France the quantitative importance of agritourism in the population of farmers is very limited if one does not consider the direct selling of products (DS): $2,8 \%$ of the whole in 2000 . But the number of agritourism farms is maintaining when the global population of farms is declining, so this rate is growing.

More important, the rate of farms declaring some form of direct selling (DS) is high: $15 \%$. The part of this rate which is relevant in agritourism is difficult to estimate, because: 1 - some of these $15 \%$ are just selling a marginal part of their products, 2- some are not selling to the end consumer, 3- some are selling only to local inhabitants, in contexts where tourism may be totally absent.

\section{Organization of agritourism sub-sector}

The global organization of agritourism in France is following (the data are drawn from Perret et Marcelpoil 2001):

- The consular chambers of agriculture are responsible for 1- advising all the farmers in their activity and for their projects, 2- representing them in so far as their specific agritourism activity is recognized as belonging to the agricultural sector. They created a brand and a network for enhancing this role, and especially in the domain of marketing (Bienvenue à la ferme). In the year 2000, for whole France, this brand covered 3.800 services to offer.

- Other networks gather farmers in relation with agritourism: "Accueil Paysan" is specialized in agritourism, but not linked with the Chambers, "CIVAM" is more generally active in rural development. Some networks of tourism businesses may include farmers: main example is 
the network of accommodation owners (Gîtes de France: 54.000 cottages in 2000) which originally counted a strong amount of farmers, today roughly $25 \%{ }^{3}$.

\section{Cooperation in agritourism}

Cooperation in agritourism includes specific national agritourism networks (like Bienvenue à la Ferme or Accueil Paysan), or more local networks, and other organizational forms.

Alliances or networks may be classified in two categories: vertical ones or horizontal ones. Vertical alliances link complementary activities constituting some kind of "supply chains". Horizontal ones link similar activities, as do networks of accommodation providers (Violier 1995), or cheese or wine routes (cf supra). (Hjalager 1996) assesses networks in agritourism are successful mostly in the domain of marketing, but sometimes not very efficient. She compared the wealth of formalized cooperative forms in other farming spheres and their near absence in agritourism; the difference in kind between material products and services mainly explains this fact ${ }^{4}$. More generally she stresses also that agritourism farmers are often less influential in professional spheres. However (Telfer 2000) reckons that the role of alliances, networks and collective action is essential in the development of rural areas.

\section{Method}

The global work on agritourism associates a case study in a destination of diffuse tourism where agritourism is a major component of the offer, and a regional exploratory study in order to help designing the new regional policy for agritourism. The present text tells mainly about one part of this second study at the scale of the region; but some information is also drawn from the first local study.

The methodology articulates several tasks:

- The local study, dealing with global tourism including agritourism, was led in south Auvergne (La Chataigneraie cantalienne). It consisted in a survey of a wide range of actors (40 in-depth interviews lasting 2 hours in average:

o Tourist business owners, including farmers

o Institutional actors, either in sectorial organizations (like TO, CDT, Chamber of agriculture), or in territorial organizations (groups of communes)

- The regional study included as main tasks

o a survey of the actors of main networks in agritourism and related institutional organizations:

- the 4 networks "Bienvenue à la ferme" in the 4 départements, and the regional chamber of agriculture

- the networks "Accueil paysan" ("peasant welcoming") and "regional federation of CIVAM" (Initiative Centres for valorising agriculture and rural areas)

- as secondary sources of information the regional and "departemental" Committees of tourism were also interviewed

So the survey counted 13 in-depth interviews (2 to 3 hours) with the 6 animators of network, and 7 related actors.

The questionnaire dealt with following topics: internal organization / information on the offer / information on the demand / external organization (relationship, governance) / prospective / suggestions

\footnotetext{
${ }^{3}$ Gîtes de France does not distinguish its members who are farmers specifically anymore.

${ }^{4}$ The rule of cooperatives is suitable for horizontal sharing of products, but much less for vertical complementarity where actors are not economically equal. We found one example in France, the cooperative of accommodation providers in the department of Hérault (Morand, 1999, Marsat, 2000).
} 
o a work of benchmarking was also led by the comparison with the organisation of agritourism in the Région Aquitaine (3 institutional actors were interviewed) and in the Département of Dordogne (2 interviews of the responsible of agritourism at the Chamber of agriculture). The available documentation also was analysed.

\section{Results}

\section{Questions of definition or delimitation}

Different actors have a different vision of the contours of agritourism, some exclude direct sales of farming products because the link to tourism depends on local situations, the others exclude accommodation if it is not linked with the activity of the farm. We propose the following conceptual diagram (Figure 2) to situate the diverse activities by intersecting their link with agriculture and their link with tourism. These links can be defined by diverse criteria, turnover, employment, or the experience of the tourist, etc. This leads to different concrete classifications.

We chose to take into account the whole range of activities. Our benchmarking task showed the effects of a similar choice made by the actors in the Dordogne. In this Département, where agritourism is most developed, the actors show a preference for economic dynamism, versus professional purity; the Chamber of agriculture works in all sub-domains, including direct selling (not only on the farm but also in markets or to distributors, and to restaurants ${ }^{5}$ ). This attitude was/is still somehow in discordance with the initial choices of the national network of chambers, but this one is conduced to take it into account.

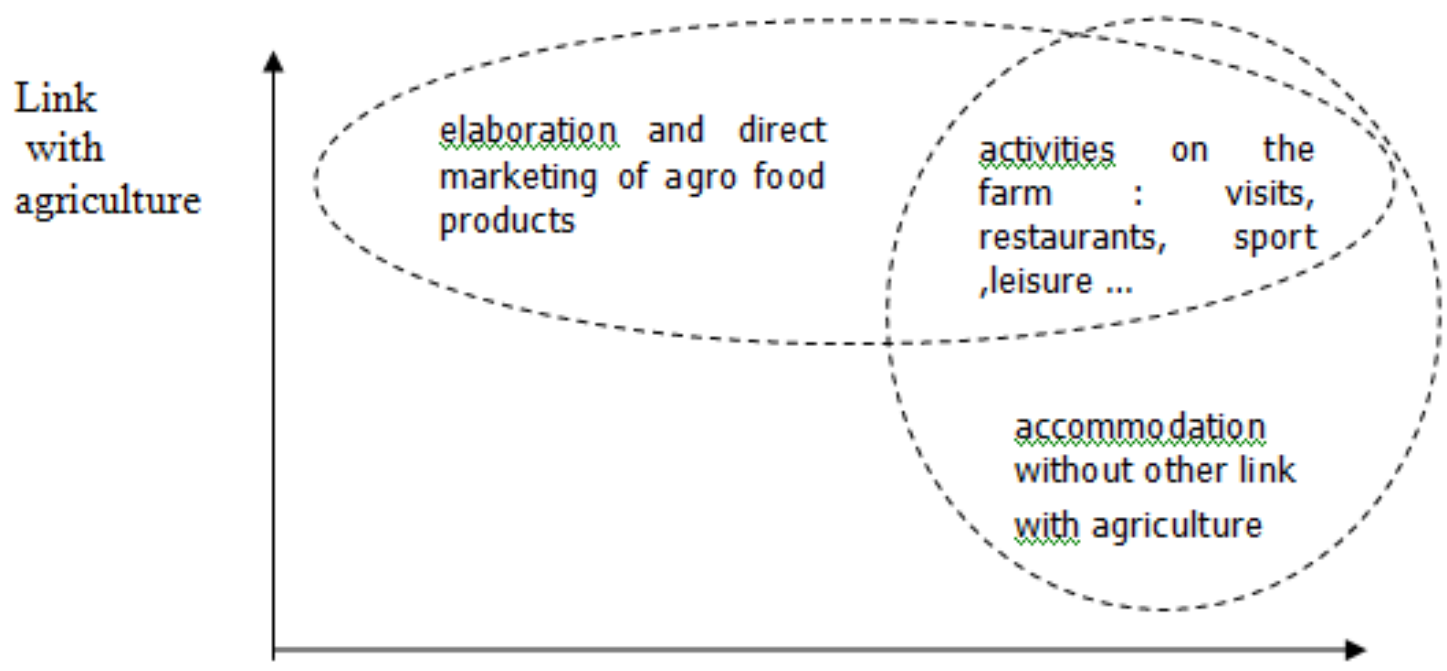

Link with tourism

Fig 2. Typology of activities that fall within the scope of agritourism (own elaboration).

\subsection{General quantitative indications in Auvergne}

The population of farmers diversified in agritourism is a small minority, in Auvergne like in France.

The recent publication of the exhaustive census of farms gives following data:

- 23.700 is the total amount of farms in the region

- 600 farms propose accommodation, catering or leisure activities.

- 1.500 farms sell some product directly on the farm (770 on markets, 730 to small retailers)

\footnotetext{
${ }^{5}$ It created a special cooperative society for selling to collective restaurants.
} 
The rate of those who join one of the networks is relatively high, excepted in the domain of direct selling. The amount of members of the agritourism networks, or networks including agritourism is:

- $\quad 377$ farms in the 6 studied networks

- 180 accommodation offers marked "on the farm" in the network Gîte de FranceAuvergne (among a whole of 2.900 ), some others in smaller more specialised networks (Rando accueil)

- Some farms belong to local networks specialised in direct selling of products with or without visits and explanations on the farm ${ }^{6}$.

\subsection{Organization of agritourism: specific actors, active organizations and networks}

\section{A relative high level of support, with some limits}

Agritourism benefits from the high level of the general support available in the agricultural sector, through strong and active consular chambers and trade unions. A systematic networking has been developed by the Chambers and play an important role for the members: advice, training, marketing (with a national brand in the case of Bienvenue à la ferme), and lobbying. The same consular actor can bring to the farmer specific support in agritourism and also all generic support concerning technical, economical, judicial, social questions in agriculture. As comparative point, the chambers of commerce and industry bring the same kind of support to hotel owners, coupling specific advice in tourism and generic support in business. But it does not include systematically the marketing side with a national brand. And it is historically focused on hotel business and does not cover the same variety of tourism services as the chambers of agriculture do for agritourism.

The two other surveyed networks bring also useful and active support. One must add the tourism networks which historically come from agri-rural areas and actors, like Gîtes de France.

The interviewed network organizers think they could do more with more (human) means. One of the networks evokes also financial difficulties. One stake is the range and profitability of services a network can bring to farmers or to other stakeholders. For example it can create and sell training services, but in a competitive context.

Important point is the change in the regional policy of financial support: previously regular grant was given to organizations like these networks. This policy changed recently, the direct aids to the organizations were removed. The philosophy is now to let the business owner choose himself to what extend he needs the services and support, and to what extend he wants to pay them. According to the work of (Olson 1966), it may lead to reduce collective action. This may be a research question for the future.

\section{Relation between agritourism networks: a deficit, some "political" reasons}

All interviewees acknowledge a deficit in the relationship between the family of the 4 networks "Bienvenue à la ferme", and the two other networks (Accueil Paysan and FRCIVAM). Especially the latter ones, which are smaller, regret this fact, and stress there should be more cooperation. Over all they claim for an equal recognition from the institutional partners.

There is much to share, for example knowledge of the clientele, or training ... In that domain an external (institutional) organization may offer a common service, or broadcast information, but the elaboration of the right strategy for sharing or collaborating depends on the agritourism actors themselves.

So, to favour better coordination between networks could be an aim for the regional policy. It will have to deal with the political dimension of the present dichotomy. Roughly almost all the consular chambers follow the political mainstream in the agricultural sphere, whereas Accueil Paysan, and least the CIVAM are closer to an alternative view of agriculture, which they

\footnotetext{
${ }^{6}$ networks : La Jonquille, Route des métiers, Route des fromages d'Auvergne, Coopérative acajou...
} 
say to be less productivist, more humanist. This difference has a correspondence in the respective visions of agritourism.

Interviewees acknowledge that cooperation will not occur spontaneously, but on the other hand, they do not want a too strong top-down policy which would want to simply "marry" the networks. A way is to propose common projects, despite the cost in time and effort (recent example of elaborating exhaustive list of DS producers in one of the Départements).

On the other hand

\section{A need of strategy}

Several interviewees acknowledged a dominant day-to-day involvement and a lack in elaborated and shared strategy, at the scale of their network, or the family of the 4 Bienvenue à la Ferme networks, but also at the scale of all organizations working in agritourism.

The stake is linked to the previously mentioned deficit in inter-organizational relationship (who has legitimacy to exert a strategic leadership?). It is also linked to the deficit in information on the whole population of agritourism farms, on the demand and its prospective, on the place of agritourism in global tourism.

\subsection{Relation between sectors of tourism and agritourism: at the local level}

\section{Possible contribution of agritourism to qualifying the destinations, especially in diffuse tourism}

The Modintour program chose, as common research question for all working packages, the question of the supposed opposition between diffuse tourism and concentrated tourism. We proposed three dimensions for describing and evaluating a situation: the spatial one, the temporal one (seasonal), and the organizational one. As result of 4 detailed case studies, in the global program, we showed that real situations in the diverse destinations are neither totally diffuse nor totally concentrated.

In the regional study, all interviewees said "agritourism belongs naturally to diffuse tourism". The offer of an individual farm is limited (up to several bedrooms), and the natural dispersion of the farms due to their agricultural activity cannot lead to a concentrated agritourism offer. One of the networks goes further and rejects philosophically the model of "mass tourism".

Some interviewees acknowledged the difficulties that the spatial dispersion of tourism and agritourism businesses brings: it needs more energy for working in each compartment (marketing, networking...): for example it is more difficult for a business to build a sufficient offer of activities on the farm and around. But it was acknowledged that some farmers in agritourism succeeded in it. On the other hand, some destinations of rather concentrated tourism, but not all, may include offers in agritourism. These ones benefit from a rich tourism context, but suffer from negative externalities in their agricultural activity. Tourism in return benefits from agritourism as a way of diversification, like ski resorts which now want to develop the summer season.

For most respondents, agritourism is a chance for rural destinations, and brings richness and diversity in their offer. Some TO acknowledged this effect. It is so in the case of Chataigneraie cantalienne: agritourism brings the third of accommodation businesses, agriculture takes care of a mild diversified landscape, local agricultural products gave an identity to this area, and still they are the basis of a lot of local feasts (Marsat, Bonniot, Bouchaud, Monin, and Menegazzi 2011).

\section{Interdependence between development of agritourism and development of the destination}

We make the hypothesis of a double dynamic: 1- a sub-sectorial one (the industry or filière), specific to agritourism 2- a territorial one, specific to each destination. 
Previous section tells about positive effect of agritourism on the destination. Some stakes are specific to this industry (the "filière"): its organization, hence its ability to find solutions, products and market shares, notoriety, to bring specific operating coordination.

In parallel, agritourism depends locally on the health of the destinations. From a pragmatic point of view, the interviewed responsible of the local TO stresses the conditions for the development of the destination in its whole, in particular to gain more notoriety, more assistance from the marketing organizations at the upper level (Département, Région). From a policy point of view, the specific wish to support agritourism could lead to a specific support of this type of destination.

From an analytical point of view, there is a link between the type of territory/destination and the type of agritourism which may be found in. The importance of the territorial context was particularly emphasized by (Perret and Marcelpoil 2001) who built a typology of the couples "types of territories-forms of agritourism". They did not look for any causality between the two terms, but assumed that such a typology has to be taken into account for the design of public policies.

\section{A lack of coordination locally between actors of agritourism and actors of global tourism}

There are few local agritourism networks, and the involvement of farmers in local general tourism networks (i.e which are not specialised in agritourism) is limited.

The interviewed network animators work at the scale of a "department" or a region, they ignore to what extend the farmers they know are involved locally in the governance of their tourist destinations, or how they are involved in other tourism networks. These animators play a parttime role of project developers which leads them occasionally to a local, territorial involvement: they may for example create once an equestrian circuit. This role is limited in comparison to the work of the many local tourist offices (TO) and other development agents.

Relation between agritourism networks and Tourism Offices are said to be good, but examples of operational cooperation were given as only single cases. At the upper level of the Départements, none of the employees of the 4 Committees of tourism (CDT) was in charge of agritourism: the 4 CDT told us to interview directly the chambers of agriculture.

The territorial actors, namely the "communes" and their groups are also main stakeholders. They have technical teams involved in socio-economic development and may act in many ways in favour of tourism, including agritourism.

We suggest the scheme of cooperation between these three types of stakeholders: territorial actors, tourism actors and agriculture/agritourism actors. Instead of total cooperation between institutional organizations, we observed some concerns expressed about possible competition. It is in accordance with the question of better involvement of the Consular chambers (industry, commerce, trade, agriculture) in the matter of territorial development (ISEOR 2003).

In brief a stake is to enhance the cooperation in local tourist destinations. We consider it can be achieved in both dimensions: dynamically through common projects, and structurally through appropriate design of the local organization. Common projects may be encouraged for example by specific policies, as does the EU with its Leader programs.

\subsection{At the regional level}

\section{Mixed organizational and cultural stakes}

Which is the best organization for conceiving and operating a regional policy in favour of agritourism? Should it be given to the office in charge of agriculture, or to the office in charge of tourism? Has the policy scheme to be specific?

In the region Auvergne, a change occurred in 2011, transferring the responsibility to the office in charge of tourism, assisted by the regional Committee of tourism (CRT). This one expressed hence a demand for more information about this domain; in the same time it adopted a first draft of its new policy scheme for agritourism. Central question is to know which specificity from 
agricultural sphere is to be maintained, and which policy framework is to be applied in common with overall tourism sector.

The most visible decision early adopted in Auvergne was to apply the tourism policy framework called "Nattitude", to the new procedure of granting agritourism investments and projects. Nattitude is a quasi-brand, it is originally a set of criteria for estimating the quality of a project before according grants. Then the elected business owner gains promotional assistance (with Nattitude image) and other advices. The whole process conduced to a new network, animated directly by the regional CRT. The logic of Nattitude is market-driven, it aims to promote a higher quality in the regional offer. In the facts this higher quality means often (even if not always) a higher position in the range of offers, and higher prices.

The interviewed actors in the agricultural sphere, stress several possible concerns:

\section{Importance of maintaining the agricultural identity and the global vision of the farm}

Interviewees expressed a specific identity of all farmers engaged in agritourism. In that respect, they are different from other tourism business owners: "take care not to want they would be only professionals in tourism", "tourism actors don't know how to address farmers, it is more complex, they have two professions".

For the animators of agritourism networks, in their role of support, the concern is specific for agritourism, as junction between two domains: "there is no reason for distinguishing agritourism and other activities on the farm", "it is not easy for us to split a global project in order to present it to two different services of the region".

\section{Diversity of individual logics}

This second concern is not specific for agritourism; examples of particularities are expressed: "not all farmers are willing to offer their tourism services to upper-class clientele", "not all farmers are willing to adhere to central reservation systems".

Diversity of logics may be considered from a political point of view, but also from a marketing one: (Perret and Marcelpoil 2001) stressed the risk of making the offer too much uniform in agritourism (like in whole tourism). Such standardization may proceed from dominant actors with their choices: CRT chooses de facto limited segments of clientele in the case of Nattitude, the dominant national network of cottages Gîtes de France has a policy of strict standardization, and so on.

\section{Like at the local level an action is possible on structural partnership}

Like at the local level, it is possible to reinforce a partnership between organizations in charge of tourism (CRT) and of agriculture (regional Consular chamber...). At every scale, the difficulty is twofold: 1- to explicit the political reasons and the global framework for partnership, 2- to create the conditions for efficiency.

For example the director of the CDT in the Département du Doubs explained the mechanism of such a partnership: "one representative of the chamber of agriculture participates regularly to our strategic debates in the framework of an assembly including actors of tourism and other actors. He participates actively to work groups about tourism development, about external fairs, about commercial strategy, and so on. Tight links are also active with technicians of the chamber, about individual projects of the farmers." (magazine "Chambres d'agriculture", 2008)

\section{Conclusions and discussion}

In summary this study gave mostly qualitative information on the organization of agritourism in Auvergne: assessment of a relative high level of support but with a need of better cooperation between networks, a need of global strategic view and orientation, a need of better integration in global tourism organization. Relation between actors of agritourism and actors of global tourism are highly perfectible. It needs occasions and places for contact and collaboration. It 
needs recognition of the specificity of agritourism entrepreneurs, who have to link two types of professionalization and two cultures.

\section{The need of further knowledge is important.}

Quantitative knowledge is still weak, due to difficulties in the identification of farmers in global networks, or in very local ones, due also to the fuzzy definition of the link between tourism and direct selling of agricultural products.

A need of knowledge of the concrete "business models" of agritourism farms in a given region is also real and is expressed by regional actors. Some national studies give such models and data but in average situations, without regional context.

The knowledge of tourism business owners on their clientele is often weak, it is an evidence in the case of agritourism. Beyond punctual studies, one can reflect about the permanent means to enhance this capacity.

The limits to direct cooperation between farmers and the way to achieve it in the form of tight alliances (in domains beyond the marketing one, such as employment, production, innovation ...) are still to revisit.

The territorial integration of agritourism, its place in the governance of tourism destinations is also to be studied further. This is a major illustration of the question of crossing "filière" ${ }^{7}$ and "territoire" 8 approaches. More generally, a wider research would deal with the questions of the multiple roles of all farmers in the destination. As exposed in the theoretical section of this text, all the farmers act as "operators of amenities", and amenities are main resource for tourism. This research could include a question on the place of agritourism in the perception of this role by farmers, and about the possible means to involve them deeper.

Finally the present work has to be deepened relatively to the need for agritourism to adopt all relevant skills from global tourism, balanced by the need for tourism to make a right place to this form of diversity, either for ethical / political motives or for strategic / marketing motives.

\section{References}

[1] Bachimon, P. (1995). Tourisme de masse - tourisme diffus en espace rural - exemple de la basse vallée de l'Ardèche (pp. 20-33). In Vitte, P. \& Jamot, C., eds., Le tourisme diffus. Clermont Ferrand: CERAMAC.

[2] Berger-Doucé, S. (2004). La démarche collective, catalyseur de l'engagement environnemental en PME? (p. 27) In 13è conférence de l'AIMS. Normandie-vallée de Seine: AIMS.

[3] Bramwell, B. \& Sharman, A. (1999). Collaboration in local tourism policymaking. Annals of Tourism Research 26(2), 392-415. Doi: 10.1016/S0160-7383(98)00105-4.

[4] Buhalis, D. (2000). Marketing the competitive destination of the future. Tourism Management 21(1), 97-116. Doi: 10.1016/S0261-5177(99)00095-3.

[5] Callegati, E. \& Grandi, S. (2004). Cluster dynamics and innovation in SMEs: the role of culture." (p. 10). In Ebla international workshop 2004 - Clusters, districts, and networks of tangible, intangible and material cultural heritage, in the non-eu mediterranean countries. Torino: Università degli Studi di Torino.

[6] Cattellin, M. (2008). Modes de coordination, réseaux interorganisationnels et avantage concurrentiel: une application à une destination touristique des Alpes. (p. 35). Journée Rochelaise de Recherche sur le Tourisme. La Rochelle: Ecole Superieure de Commerce.

\footnotetext{
${ }^{7}$ term which we could translate by "industry"

${ }^{8}$ the "destination" which gathers local instances of diverse filières, the whole being embedded in all the dimensions of community
} 
[7] Dredge, D. (2006). Policy networks and the local organisation of tourism. Tourism Management 27(2), 269-280. Doi: 10.1016/j.tourman.2004.10.003.

[8] Fabry, N. (2009). Clusters de tourisme, compétitivité des acteurs et attractivité des territoires. Revue internationale d'intelligence économique 1(1), 55-66. Doi : 10.3166/r2ie.1.55-66.

[9] Fombrun, C. J. \& Graham Astley, W. (1983). Beyond corporate strategy. The journal of business strategy 3(4), 47-54. Doi: 10.1108/eb038989.

[10] Gray, B. (1989). Collaborating: finding common ground for multiparty problems. Oxford: Jossey-Bass Publishers.

[11] Gundolf, K., Jaouen, A. \& Loup, S. (2006). Institutions locales et TPE dans le cas du tourisme (pp. 141-156). In Gestion d. R. F., ed., Les stratégies collectives à l'épreuve des faits, vol. 32, Paris: Lavoisier.

[12] Hakansson, H. \& Deo Sharma, D. (1996). Strategic alliance in a network perspective (pp. 108-124). In Networks in Marketing. London: SAGE Publications.

[13] Halme, M. (2001). Learning for sustainable development in tourism networks. Business Strategy and the Environment 10(2), 100-114. Doi: 10.1002/bse.278.

[14] Hjalager, A. (1996). Agricultural diversification into tourism - Evidence of a European Community development programme. Tourism Management 17(2), 103-111. Doi: 10.1016/0261-5177(95)00113-1.

[15] Huybers, T. \& Bennett, J. (2003). Inter-firm cooperation at nature-based tourism $\begin{array}{llll}\text { destinations. Journal of Socio-Economics } & 32(5),\end{array}$ Doi: 10.1016/j.socec.2003.08.011.

[16] Ilbery, B., Bowler, I., Clark, G., Crockette, A. \& Shaw, A. (1998). Farm-based Tourism as an alternative farm enterprise: a case study from the Northern Pennines, England. Regional studies 32(4), 355-364. Doi: 10.1080/00343409850117816.

[17] ISEOR (2003). Mutation stratégique des chambres de commerce et d'industrie. Lyon: ECONOMICA.

[18] Jamal, T. B. \& Getz, D. (1995). Collaboration theory and community tourism planning. Annals of Tourism Research 22(1), 186-204. Doi: 10.1016/0160-7383(94)00067-3.

[19] Jarillo, J. C. (1988). On strategic networks. Strategic Management Journal 9(1), 31-41. Doi: $10.1002 / \mathrm{smj} .4250090104$.

[20] Knafou, R. (1995). Incertitudes, paradoxes et ambiguités du tourisme diffus (pp. 5-16). In Le tourisme diffus. Clermont Ferrand: CERAMAC.

[21] Marsat, J.-B. (2007). Le réseau, un objet de gestion stratégique pour des dynamiques territoriales de développement durable - applications en tourisme. In XLIIlè colloque de I'ASRDLF - Les dynamiques territoriales - Débats et enjeux entre les différentes approches disciplinaires. Grenoble - Chambéry: ASRDLF.

[22] Marsat, J.-B. \& Bonniot, A. (2009). Programme Modintour - DO- Cadre conceptuel., Clermont-Ferrand: UMR METAFORT - Irstea.

[23] Marsat, J.-B., Bonniot, A., Bouchaud, M., Monin, C. \& Menegazzi, P. (2011). Territorial Integrated Tourism: dispersion, complementarity, social embeddedness and governance conceptual framework and evidence in Auvergne (France). Paper read in the $19^{\text {th }}$ Annual Colloquium of the International Geographical Union Commission, Galway.

[24] Marsat, J.-B. \& Guerra, F. (2011). Les systèmes relationnels des prestataires de tourisme: caractérisation et enjeux pour le management local - étude de cas dans le Massif du Sancy. Paper read in the XLVIII è Colloque de l'Association de Science Régionale de Langue Française (ASRDLF). Schoelcher: ASRDLF. 
[25] Miles, R. E. \& Snow, C. C. (1986). Organizations: new concepts for new forms. California management review 28(3), 62-73.

[26] Novelli, M., Schmitz, B. \& Spencer, T. (2006). Networks, clusters and innovation in tourism: a UK experience. Tourism Management 27(6), 1141-1152. Doi: 10.1016/j.tourman.2005.11.011.

[27] OCDE (2000). Valuing rural amenities. Paris: OCDE.

[28] Olson, M. (1966). La logique de l'action collective. Cambridge (Mass.): Harvard University Press.

[29] Perret, J. \& Marcelpoil, E. (2001). L'agritourisme en 2001 - La diversité des territoires et des acteurs: entre témoignage et commerce. Grenoble: Cemagref.

[30] Porter, M. E. (1980). Competitive Strategy. New York: The Free Press.

[31] Selin, S. (1993). Collaborative Alliances: New Interorganizational Forms in Tourism (pp. 217-227). In Uysal, M. \& Fessenmeier D. N, eds., Communication and channel systems in tourism marketing: New York: The Haworth Press.

[32] Selin, S. \& Chavez, D. (1995). Developing an evolutionary tourism partnership model. Annals of Tourism Research 22(4), 844-856. Doi: 10.1016/0160-7383(95)00017-X.

[33] Sheehan, L. R. \& Brent Ritchie, J. R. (2005). Destination stakeholders - exploring identity and salience. Annals of Tourism Research 32(3), 711-734. Doi: 10.1016/j.annals.2004.10.013.

[34] Stokes, R. (2003). Interorganisational relationships for event tourisme strategy making in Australian states and territories. Griffith: School of tourism and hotel management.

[35] Telfer, D. J. (2001). Strategic alliances along the Niagara Wine Route. Tourism Management 22(1), 21-30. Doi: 10.1016/j.annals.2004.10.013.

[36] Tremblay, P. (1998). The economic organisation of tourism. Annals of Tourism Research 25(4), 837-859. Doi: 10.1016/S0160-7383(98)00028-0.

[37] Truly-Sauter, E. \& Leisen, B. (1999). Managing stakeholders - a tourism planning model. Annals of Tourism Research 26(2), 312-328. Doi: 10.1016/S0160-7383(98)00097-8.

[38] Vandecandelaere, E. \& Touzard, J.-M. (2001). Les routes des vins: des réseaux de proximité territoriale. Paper read in Troisième congrès sur la proximité: nouvelle croissance et territoires. Paris: Université Paris Sud et INRA.

[39] Vernon, J., Essex, S., Pinder, D. \& Curry, K. (2005). Collaborative policymaking - local sustainable projects. Annals of Tourism Research 32(2), 325-345. Doi: 10.1016/j.annals.2004.06.005.

[40] Violier, P. (1995). Tourisme diffus et agritourisme dans l'Ouest de la France. (pp. 45-62). In Vitte, P. \& Jamot, C. Le tourisme diffus. Clermont Ferrand: CERAMAC. 